\title{
Phytoprotection
}

\section{Effects of surface wetness duration, temperature, and inoculum concentration on infection of winter barley by Rhynchosporium secalis}

\section{G. Xue et R. Hall}

Volume 73, numéro 2, 1992

URI : https://id.erudit.org/iderudit/706020ar

DOI : https://doi.org/10.7202/706020ar

Aller au sommaire du numéro

Éditeur(s)

Société de protection des plantes du Québec (SPPQ)l

ISSN

0031-9511 (imprimé)

1710-1603 (numérique)

Découvrir la revue

Citer cet article

Xue, G. \& Hall, R. (1992). Effects of surface wetness duration, temperature, and inoculum concentration on infection of winter barley by Rhynchosporium secalis. Phytoprotection, 73(2), 61-68. https://doi.org/10.7202/706020ar
Résumé de l'article

Nous avons étudié les effets de la durée d'humectation, de la température et de la concentration de l'inoculum sur le développement de la rhynchosporiose chez l'orge d'automne (Hordeum vulgare) inoculée avec la race SO1 du Rhynchosporium secalis du sud de l'Ontario (Canada). Sur la ignée d'orge GW8614 vaporisée avec une suspension de spores $\left(2 \times 10^{5}\right.$ conidies $\left.\mathrm{mL}^{-1}\right)$, des périodes d'humectation de 2-48 $\mathrm{h}$ et des températures de $0-25^{\circ} \mathrm{C}$ pendant les périodes humides et sèches, de $10-25^{\circ} \mathrm{C}$ pendant la période humide et de $20^{\circ} \mathrm{C}$ pendant la période sèche, ou $20^{\circ} \mathrm{C}$ pendant la période humide et $10-30^{\circ} \mathrm{C}$ pendant la période sèche ont permis le développement de la rhynchosporiose 8,3-11,5 jours après l'inoculation. La maladie s'est développée plus rapidement et plus intensément quand la période humide après l'inoculation était de $48 \mathrm{~h}$ et quand la température de la période humide et de la période sèche subséquente était de $20^{\circ} \mathrm{C}$. La hynchosporiose ne s'est pas développée à l'intérieur de 14 jours suite à des yempératures de $30^{\circ} \mathrm{C}$ pendant la période humide ou de $5{ }^{\circ} \mathrm{C}$ pendant les périodes humides ou sèches. À des concentrations d'inoculum de $10^{2}-10^{6}$ conidies $\mathrm{mL}^{-1}$, l'indice de gravité (échelle de 0-100) a augmenté de 53 à 100 pour la lignée GW8614 et de 0 à 90 pour le cultivar OAC Acton et les périodes latentes ont diminué de 13,3 à 7,8 jours pour la lignée GW8614 et de plus de 14 à , 5 jours pour le cultivar OAC Acton. Ces renseignements devraient faciliter le criblage de cultivars d'orge résistants à la rhynchosporiose. 


\title{
Effects of surface wetness duration, temperature, and inoculum concentration on infection of winter barley by Rhynchosporium secalis
}

\author{
Guoxing Xue and Robert Hall ${ }^{1}$
}

Received 1992-06-10; accepted 1992-09-23

The effects of surface wetness duration, temperature, and inoculum concentration on development of scald in winter barley (Hordeum vulgare) inoculated with race SO1 of Rhynchosporium secalis from southern Ontario, Canada were examined. On barley line 'GW8614' sprayed with a spore suspension $\left(2 \times 10^{5}\right.$ conidia $\left.\mathrm{mL}^{-1}\right)$, wet periods of $2-48 \mathrm{~h}$ and constant temperatures of $10-25^{\circ} \mathrm{C}$ during the wet and dry periods, $10-25^{\circ} \mathrm{C}$ during the wet period and $20^{\circ} \mathrm{C}$ during the dry period, or $20^{\circ} \mathrm{C}$ during the wet period and $10-30^{\circ} \mathrm{C}$ during the dry period allowed scald to develop 8.3-11.5 d after inoculation. The disease developed most rapidly and most severely when the wet period after inoculation was $48 \mathrm{~h}$ and the temperature of the wet period and subsequent dry period was $20^{\circ} \mathrm{C}$. Scald did not develop within $14 \mathrm{~d}$ following temperatures of $30^{\circ} \mathrm{C}$ during the wet period or of $5^{\circ} \mathrm{C}$ during the wet or dry periods. At inoculum densities of $10^{2}-10^{6}$ conidia $\mathrm{mL}^{-1}$, the disease severity index values (0-100 scale) increased from 53 to 100 in line 'GW8614' and from 0 to 90 in cultivar OAC Acton and the latent periods decreased from 13.3 to $7.8 \mathrm{~d}$ in line 'GW8614' and from more than 14 to $8.5 \mathrm{~d}$ in cv. OAC Acton. This information should facilitate screening of barley for resistance to scald.

Xue, G., and R. Hall. 1992. Effects of surface wetness duration, temperature, and inoculum concentration on infection of winter barley by Rhynchosporium secalis. PHYTOPROTECTION 73: 61-68.

Nous avons étudié les effets de la durée d'humectation, de la température et de la concentration de l'inoculum sur le développement de la rhynchosporiose chez l'orge d'automne (Hordeum vulgare) inoculée avec la race SO1 du Rhynchosporium secalis du sud de l'Ontario (Canada). Sur la lignée d'orge GW8614 vaporisée avec une suspension de spores $\left(2 \times 10^{5}\right.$ conidies $\left.\mathrm{mL}^{-1}\right)$, des périodes $\mathrm{d}^{\prime}$ humectation de 2-48 h et des températures de $10-25^{\circ} \mathrm{C}$ pendant les périodes humides et sèches, de $10-25^{\circ} \mathrm{C}$ pendant la période humide et de $20^{\circ} \mathrm{C}$ pendant la période sèche, ou $20^{\circ} \mathrm{C}$ pendant la période humide et $10-30{ }^{\circ} \mathrm{C}$ pendant la période sèche ont permis le développement de la rhynchosporiose 8,3-11,5 jours après l'inoculation. La maladie s'est développée plus rapidement et plus intensément quand la période humide après l'inoculation était de $48 \mathrm{~h}$ et quand la température de la période humide et de la période sèche subséquente était de $20^{\circ} \mathrm{C}$. La rhynchosporiose ne s'est pas développée à l'intérieur de 14 jours suite à des températures de $30^{\circ} \mathrm{C}$ pendant la période humide ou de $5^{\circ} \mathrm{C}$ pendant les périodes humides ou sèches. À des concentrations d'inoculum de $10^{2}-10^{6}$ conidies $\mathrm{mL}^{-1}$, l'indice de gravité (échelle de 0-100) a augmenté de 53 à 100 pour

\footnotetext{
1. Department of Environmental Biology, University of Guelph, Guelph, Ontario,
} Canada N1G 2W1 
la lignée GW8614 et de 0 à 90 pour le cultivar OAC Acton et les périodes latentes ont diminué de 13,3 à 7,8 jours pour la lignée GW8614 et de plus de 14 à 8,5 jours pour le cultivar OAC Acton. Ces renseignements devraient faciliter le criblage de cultivars d'orge résistants à la rhynchosporiose.

\section{INTRODUCTION}

\begin{abstract}
Scald of barley (Hordeum vulgare L.), caused by Rhynchosporium secalis (Oudem.) J.J. Davis, causes significant yield losses in many barley production areas (Shipton et al. 1974) and is often severe on winter barley in Ontario (Xue and Hall 1991). The disease is controlled principally by the use of genetic resistance in the host plant. When plant germplasm is screened in controlled environments, conditions generally include a high inoculum dose $\left(2-5 \times 10^{5}\right.$ conidia $\left.\mathrm{mL}^{-1}\right)$, wetness periods after inoculation of 12-48 $h$, and incubation temperatures of 15 $25^{\circ} \mathrm{C}$ (Ali etal. 1976; Ayres and Owen 1971; Jackson and Webster 1976; Williams and Owen 1973; Xue etal. 1991). However, few reports quantify the effects of pathogen, host, and environmental variables on the development of the disease.
\end{abstract}

Severity of scald has been reported to increase (Carr et al. 1971) or to be unaffected (Ayres and Owen 1971; Schein 1960) as inoculum dose is raised but little information is available on interactions between barley genotype and inoculum dose of $R$. secalis. Skoropad (1957) and Polley (1971) examined the effects of temperature and duration of the wet period, respectively, on severity of scald, but in both studies temperatures fluctuated by several degrees centigrade during the test period. Only Ryan and Clare (1975) have reported data relating development of scald to duration and temperature of the wet period under controlled conditions. There appears to be no report on the effect of temperature on scald development when temperature is held constant between inoculation and disease assessment or between the end of the wet period and disease assessment. To rationalize methods used to screen winter barley germplasm for resistance to Ontario races of $R$. secalis, this study examined the effects of surface wetness duration, temperatures during the wet and subsequent dry periods, and inoculum density, on disease severity and latent period in winter barley inoculated with the most common race of $R$. secalis from southern Ontario.

\section{MATERIALS AND METHODS}

\section{Inoculum production and mainte- nance}

Isolate Rs018 of race SO1 of $R$. secalis (Xue 1990) was stored on unpolished porcelain beads (Lange and Boyd 1968) at $-18^{\circ} \mathrm{C}$. To produce inoculum, the beads were transferred to sterile distilled vater in a glass tube and shaken at $150 \mathrm{r} \mathrm{min}^{-1}$ for 10 min on a Burrel shaker to dislodge conidia. Aliquots $(1 \mathrm{~mL})$ of the resulting spore suspension $\left(10^{7}-10^{8}\right.$ conidia $\left.\mathrm{mL}^{-1}\right)$ were spread over the surface of wheat germ agar medium containing $100 \mathrm{mg}$ $\mathrm{L}^{-1}$ streptomycin in 9-cm-diam petri dishes (Xue 1990). The inoculated dishes were incubated at $18^{\circ} \mathrm{C}$ for $3 \mathrm{wk}$ with constant illumination from cool white fluorescent and near ultraviolet lamps. Conidia were harvested as described by Xue etal. (1991), suspended in sterile distilled water, and adjusted to the desired concentration with the aid of a hemocytometer.

\section{Plant production and inoculation}

The susceptible barley breeding line 'GW8614' and the moderately resistant cultivar OAC Acton were grown as groups of five plants in 7-cm-diam pots containing Pro-Mix BX potting mix (Plant Products Co. Ltd., Bramalea, Ontario). Plants were produced in a growth room at $20^{\circ} \mathrm{C}$ with a photoperiod of $14 \mathrm{~h}$ and a light intensity of $150 \mu \mathrm{mol} \mathrm{m} \mathrm{m}^{-2} \mathrm{~s}^{-1}$ provided by fluorescent and incandescent lamps, and were watered from the bottom of the pots twice a week. At the 3-leaf stage, $14 \mathrm{~d}$ after seeding, plants were sprayed with a spore suspension at the rate of $0.4 \mathrm{~mL}$ of spore suspension per plant using a DeVilbiss model 15 atomiser (The DeVilbiss Co., Somerset, Pennsylvania). Four replicate pots were used per treatment and all inoculated leaves were assessed on each plant. 


\section{Surface wetness duration, tempera- ture and inoculum concentration}

The effects of surface wetness duration after inoculation and temperatures of the wet period and subsequent dry period on disease development were examined in three experiments using barley line 'GW8614'. Temperatures of 5, 10, 15, 25, and $30^{\circ} \mathrm{C} \pm 1^{\circ} \mathrm{C}$ were provided by growth cabinets and a temperature of $20^{\circ} \mathrm{C} \pm 1{ }^{\circ} \mathrm{C}$ was provided by the growth room. The growth cabinets provided the same photoperiod and light intensity as the growth room. In each experiment, plants were inoculated with a spore suspension adjusted to $2 \times 10^{5}$ conidia $\mathrm{mL}^{-1}$ and placed immediately in a mist chamber located beneath the growth room bench or within individual growth cabinets for periods ranging from 1 to $48 \mathrm{~h}$. Surface wetness was maintained by a mist produced by a vaporiser. Plants were transferred from the growth room to mist chambers in the growth cabinets $6 \mathrm{~h}$ before inoculation and the lights were turned off during the wet period. At the end of the wet period surface moisture was evaporated from the plants within $15 \mathrm{~min}$ with a stream of air at room temperature.

In the first experiment, temperature was held constant at $5,10,15,20,25$ or $30^{\circ} \mathrm{C}$ throughout the wet and dry periods. In the second experiment, the temperature of the wet period ranged from 5 to $30^{\circ} \mathrm{C}$ and the temperature of the dry period was held constant at $20^{\circ} \mathrm{C}$. In the third experiment, the temperature of the wet period was $20^{\circ} \mathrm{C}$ and the temperature of the dry period ranged from 5 to $30^{\circ} \mathrm{C}$. In the fourth experiment, spore suspensions were adjusted to concentrations of $10^{2}, 10^{3}, 10^{4}, 10^{5}$, $2 \times 10^{5}, 5 \times 10^{5}$ and $10^{6}$ conidia $\mathrm{mL}^{-1}$ and sprayed onto line 'GW8614' and cV. OAC Acton as described above. Inoculated plants were exposed to a wet period of 48 $h$ and a constant temperature of $20^{\circ} \mathrm{C}$ between inoculation and disease assessment.

\section{Symptom rating and statistical analysis}

Following the wet period, plants were examined each day for symptoms of scald. The time from inoculation to onset of symptoms is referred to here as the latent period (Butt and Royle 1980). Fourteen days after inoculation, the plants were rated for disease severity on a scale of 0 4 , in which $0=$ no visible symptoms, and $1,2,3$ and 4 represent $<5 \%, 5-15 \%, 16-30 \%$ and $>30 \%$ of leaf area with visible symptoms, respectively. Symptoms included grey-green lesions that were water-soaked, pale brown lesions with a dark brown border, and extensive necrosis and desiccation of the lamina. Disease severity scores were converted to a disease severity index (DSI) from the equation

$D S I=100 \times\left(\sum\right.$ severity score $\times$ no. plants in category\})/(total no. plants $\times 4)$.

Analysis of variance was conducted (SAS Institute Inc. 1987) and treatment means were separated by the least significant difference test at a probability level of 0.05 .

\section{RESULTS}

\section{Temperature of wet and dry periods}

The effects of surface wetness duration and constant temperatures during the wet and dry periods on disease severity and latent period are shown in Table 1. No disease occurred at 5 or $30^{\circ} \mathrm{C}$ (data not shown) or following a surface wetness duration of $1 \mathrm{~h}$. The minimum duration of surface wetness required to produce disease ranged from $2 \mathrm{~h}$ at $20^{\circ} \mathrm{C}$ to $48 \mathrm{~h}$ at $25^{\circ} \mathrm{C}$. Disease occurred in the temperature range $10-25^{\circ} \mathrm{C}$ and symptoms first appeared 8.3-10.8 d after inoculation. Disease developed most rapidly at $15-20^{\circ} \mathrm{C}$ and was most severe $(D S I=100)$ at a constant temperature of $20^{\circ} \mathrm{C}$.

\section{Temperature of the wet period}

The effects of surface wetness duration and temperature of the wet period on disease severity and latent period are shown in Table 2. No disease occurred if the wet period was $1 \mathrm{~h}$ or if the temperature of the wet period was 5 or $30^{\circ} \mathrm{C}$. The minimum duration of surface wetness required to produce disease ranged from $2 \mathrm{~h}$ at 15 and $20^{\circ} \mathrm{C}$ to $9 \mathrm{~h}$ at $25^{\circ} \mathrm{C}$. Disease occurred in the temperature range of 10 $25^{\circ} \mathrm{C}$ and symptoms first appeared 8.3$10.8 \mathrm{~d}$ after inoculation. Disease develop-ed most rapidly at $15-20^{\circ} \mathrm{C}$ and was most severe $(D S I=100)$ at a wet period temperature of $20^{\circ} \mathrm{C}$. 
Table 3. Effect of surface wetness duration and temperature of the subsequent dry period on disease severity index and latent period of scald of barley ${ }^{a}$

\begin{tabular}{|c|c|c|c|c|c|c|c|c|c|c|}
\hline \multirow{3}{*}{$\begin{array}{l}\text { Surface wetness } \\
\text { duration (h) }\end{array}$} & \multicolumn{5}{|c|}{ Disease severity index ${ }^{b}$} & \multicolumn{5}{|c|}{$\begin{array}{l}\text { Latent period } \\
\text { (d) }\end{array}$} \\
\hline & \multicolumn{5}{|c|}{ Temperature $\left({ }^{\circ} \mathrm{C}\right)$} & \multicolumn{5}{|c|}{ Temperature $\left({ }^{\circ} \mathrm{C}\right)$} \\
\hline & 10 & 15 & 20 & 25 & 30 & 10 & 15 & 20 & 25 & 30 \\
\hline 1 & 0 & 0 & 0 & 0 & 0 & $-d$ & - & - & - & - \\
\hline 2 & 0 & 6 & 6 & 0 & 0 & - & 10.3 & 10.8 & - & - \\
\hline 4 & 4 & 4 & 6 & 0 & 0 & 11.3 & 11.3 & 10.3 & - & - \\
\hline 6 & 4 & 6 & 13 & 3 & 0 & 11.3 & 10.5 & 9.0 & 9.3 & - \\
\hline 9 & 6 & 10 & 12 & 4 & 1 & 11.3 & 9.5 & 9.0 & 9.5 & 9.0 \\
\hline 12 & 19 & 39 & 81 & 4 & 5 & 10.8 & 9.5 & 9.0 & 8.5 & 9.0 \\
\hline 48 & 71 & 88 & 100 & 34 & 10 & 11.5 & 9.0 & 8.3 & 8.3 & 8.5 \\
\hline $\operatorname{LSD}(P=0.05)^{\mathrm{e}}$ & 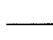 & _- & 7.5 & 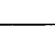 & - & 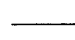 & 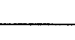 & 1.4 & & - \\
\hline
\end{tabular}

a Plants of barley line 'GW8614' were inoculated with race SO1 of Rhynchosporium secalis and then exposed to surface wetness durations of 1-48 h. Plants were exposed to $20^{\circ} \mathrm{C}$ during the wet period, and exposed to temperatures of $5-30^{\circ} \mathrm{C}$ during the subsequent dry period.

b Disease severity index (0-100 scale) was determined $14 \mathrm{~d}$ after inoculation.

c Latent period defined as period (d) from inoculation to onset of symptoms.

d - No disease. No disease occurred at $5^{\circ} \mathrm{C}$ at any period of surface wetness tested.

e LSD values refer to comparisons among all disease severity index values and among all latent periods, respectively.

Table 4. Effect of inoculum concentration on disease severity index and latent period of scald of barley $^{\mathrm{a}}$

Disease severity index ${ }^{b} \quad$ Latent period $^{\mathrm{c}}$

(d)

Inoculum concentration

(conidia $\mathrm{mL}^{-1}$ )

GW8614 OAC Acton

GW8614 OAC Acton

\begin{tabular}{lrrrr}
\hline $1 \times 10^{2}$ & 53 & 0 & 13.3 & $-\mathrm{d}$ \\
$1 \times 10^{3}$ & 73 & 8 & 11.5 & 13.8 \\
$1 \times 10^{4}$ & 84 & 8 & 10.3 & 13.5 \\
$1 \times 10^{5}$ & 87 & 39 & 7.8 & 11.0 \\
$2 \times 10^{5}$ & 100 & 79 & 7.8 & 10.0 \\
$5 \times 10^{5}$ & 100 & 86 & 8.0 & 8.8 \\
$1 \times 10^{6}$ & 100 & 90 & 7.8 & 8.5 \\
$\operatorname{LSD}(P=0.05)^{\mathrm{e}}$ & & & & \\
\cline { 2 - 4 }
\end{tabular}

a Plants of barley line 'GW8614' and cultivar OAC Acton were inoculated with race SO1 of Rhynchosporium secalis and then exposed to surface wetness for $48 \mathrm{~h}$. Plants were exposed to $20^{\circ} \mathrm{C}$ for the total period between inoculation and disease assessment.

b Disease severity index (0-100 scale) was determined $14 \mathrm{~d}$ after inoculation.

c Latent period defined as period (d) from inoculation to onset of symptoms.

d - No disease.

e LSD values refer to comparisons among all disease severity index values and among all latent periods, respectively. 


\section{Temperature of the dry period}

The effects of surface wetness duration and temperature of the dry period on disease severity and latent period are shown in Table 3. No disease occurred if the temperature of the dry period was $5^{\circ} \mathrm{C}$ (data not shown) or if the wet period was $1 \mathrm{~h}$. The minimum duration of the wet period required to produce disease ranged from $2 \mathrm{~h}$ at 15 and $20^{\circ} \mathrm{C}$ to $9 \mathrm{~h}$ at $30^{\circ} \mathrm{C}$. Disease occurred in the temperature range $10-30^{\circ} \mathrm{C}$ and symptoms first appeared 8.3-11.5 d after inoculation. Disease developed most rapidly at $20^{\circ} \mathrm{C}$ and was most severe $(D S I=100)$ at a dry period temperature of $20^{\circ} \mathrm{C}$.

\section{Inoculum concentration}

The effects of inoculum concentration on disease severity and latent period are shown in Table 4. As inoculum concentration (conidia $\mathrm{mL}^{-1}$ ) increased from $10^{2}$ to $10^{6}$, the disease severity index increased from 53 to 100 in line 'GW8614' and from 0 to $90 \mathrm{in} \mathrm{cv.} \mathrm{OAC} \mathrm{Acton.} \mathrm{In} \mathrm{the} \mathrm{same} \mathrm{range}$ of inoculum concentrations, latent period declined from 13.3 to $7.8 \mathrm{~d}$ in line ' $G W 8614$ ' and from more than 14 to $8.5 \mathrm{~d}$ in cv. OAC Acton. Maximum disease severity occurred at $2 \times 10^{5}$ conidia $\mathrm{mL}^{-1}$ in line 'GW8614' and at $10^{6}$ conidia $\mathrm{mL}^{-1}$ in $\mathrm{cV}$. OAC Acton.

\section{DISCUSSION}

Following inoculation of barley line 'GW8614' with race SO1 of $R$. secalis, scald developed most rapidly and most severely when plants were provided with a leaf wetness period of $48 \mathrm{~h}$ and were held at a constant temperature of $20^{\circ} \mathrm{C}$ during the wet and dry periods. Although each experiment was conducted only once these optimum conditions appeared in all four experiments and the data obtained for these conditions were very similar; disease severity indices were consistently 100 and latent periods ranged from 7.8 to $8.3 \mathrm{~d}$. A surface wetness duration of $48 \mathrm{~h}$ may not be necessary at optimum temperature, since a wet period of $24 \mathrm{~h}$ at a constant temperature of $20^{\circ} \mathrm{C}$ permitted maximum disease development. At wet period temperatures above and below $20^{\circ} \mathrm{C}$, disease severity declined as surface wetness duration was increased from 24 to $48 \mathrm{~h}$ (Table 2).
When the temperature of the dry period was $20^{\circ} \mathrm{C}$, disease severities were greatest and almost identical following 48-h wet period temperatures of 15 and $20^{\circ} \mathrm{C}$ and were considerably less at 10 and $25^{\circ} \mathrm{C}$ (Table 2). In contrast, under similar conditions $\left(2 \times 10^{5}\right.$ conidia $\mathrm{mL}^{-1}, 44-\mathrm{h}$ wet period, at $20^{\circ} \mathrm{C}$ day and $16^{\circ} \mathrm{C}$ night temperatures during the dry period), Ryan and Clare (1975) concluded that the disease became most severe when the temperature of the wet period was $25^{\circ} \mathrm{C}$. Moreover, they found a broader range of wet period temperatures $\left(10-25^{\circ} \mathrm{C}\right)$ that provided comparable levels of disease severity (21.3-26.4\% leaf area affected $28 \mathrm{~d}$ after inoculation). Both studies, however, found that very little or no disease developed following a wet period temperature of $30^{\circ} \mathrm{C}$. Our results are more similar to those of Skoropad (1957), who found that disease severity was greatest and latent periods were shortest (11 d) when the temperature of the wet period (duration $48 \mathrm{~h}$ ) was $15-18^{\circ} \mathrm{C}$ and the temperature of the subsequent dry period was $24^{\circ} \mathrm{C}$. In addition, Skoropad (1957) showed that appreciable disease developed at a wet period temperature of $6-14^{\circ} \mathrm{C}$ provided that the dry period temperature was $24^{\circ} \mathrm{C}$. Post-inoculation temperatures of $6-12^{\circ} \mathrm{C}$ or greater than $24^{\circ} \mathrm{C}$ greatly inhibited lesion development. It is not clear from the report whether the post-inoculation period referred to is the wet period, dry period, or both. The reports of Ryan and Clare (1975) and Skoropad (1957) together with this study indicate that temperatures at or near $20^{\circ} \mathrm{C}$ for both the wet pericid and dry period are favourable for scald development, but that the precise optimum temperature for specific combinations of barley and $R$. secalis may range from 15 to $25^{\circ} \mathrm{C}$.

When the temperature of the wet period was $20^{\circ} \mathrm{C}$, disease severities at dry period temperatures above and below the optimum $\left(20^{\circ} \mathrm{C}\right)$ were greater (Table 3 ) than when the temperature was held constant throughout the wet and dry periods (Table 1). Apparently, by favouring establishment of the fungus in the leaf, a temperature of $20^{\circ} \mathrm{C}$ during the wet period permitted earlier and more severe expression of disease symptoms when less favourable temperatures were applied subsequently. In particular, a temperatu- 
re of $30^{\circ} \mathrm{C}$ prevented infection but did not preclude expression of symptoms from established infections. Mayfield and Clare (1985) reported that scald could continue to develop if high temperatures (35 and $40^{\circ} \mathrm{C}$ ) were applied for short periods (2-6 h) at various intervals after an initial wet period of $14 \mathrm{~h}$ at $20^{\circ} \mathrm{C}$. It appears that high temperatures following successful establishment of infection do not prevent expression of symptoms.

Wet periods as short as $2 \mathrm{~h}$ permitted infection at optimum temperature. This matches the report of Ryan and Clare (1975) of a minimum wet period of $2 \mathrm{~h}$ at $20^{\circ} \mathrm{C}$. Polley (1971) reported that, under glasshouse conditions where temperatures fluctuated from 12 to $21^{\circ} \mathrm{C}$ and averaged $15^{\circ} \mathrm{C}$, the minimum wet period permitting symptom development was $9 \mathrm{~h}$. Low disease severities were also observed in this study at wet periods of up to 9 $h$ at $15^{\circ} \mathrm{C}$.

The effect of inoculum concentration on disease severity and latent period depended on the genotype of barley tested. Line 'GW8614' is more susceptible to scald than cv. OAC Acton in the field (G. Xue, personal observation) and in controlled environments (Xue et al. 1991). The present study shows that the higher susceptibility is expressed across a wide range of inoculum concentrations and is particularly evident at low inoculum levels. This suggests that inoculum doses lower than those commonly used in screening trials in controlled environments $\left(2-5 \times 10^{5} \mathrm{co}-\right.$ nidia $\mathrm{mL}^{-1}$ ) may be useful in detecting quantitative resistance in barley to scald.

In summary, infection and disease can occur within the range $10-25^{\circ} \mathrm{C}$ for many combinations of barley and $R$. secalis genotypes. The optimum temperatures for infection and disease development vary widely within the pathosystem, ranging from 15 to $25^{\circ} \mathrm{C}$. Disease can occur after $2 \mathrm{~h}$ of surface wetness but maximum disease occurs after 24-48 h. Disease severity increases with inoculum concentration but the dose-response curve depends on the genotype of the host.

\section{ACKNOWLEDGEMENT}

We gratefully acknowledge the financial support provided by the Canadian International Development Agency through the Black Dragon River Consortium, by the Natural Sciences and Engineering Research Council of Canada, and by the Ontario Ministry of Agriculture and Food.

\section{REFERENCES}

Ali, S.M., A.H. Mayfield, and B.G. Clare. 1976. Pathogenicity of 203 isolates of Rhynchosporium secalis on 21 barley cultivars. Physiol. Plant Pathol. 9: 135-143.

Ayres, P.G., and H. Owen. 1971. Resistance of barley varieties to establishment of subcuticular mycelia by Rhynchosporium secalis. Trans. Br. Mycol. Soc. 57: 233-240.

Butt, D.J., and D.J. Royle. 1980. The importance of terms and definitions for a conceptually unified epidemiology. Pages 29-45 in J. Palti, and J. Kranz (eds.), Comparative epidemiology. Centre for Agricultural Publishing and Documentation, Wageningen.

Carr, A.J.H., B.C. Clifford, R. Cook, R.M. Habgood, J.D. Hayes, and I.T. Jones. 1971. Report of the Welsh Plant Breeding Station 1970: 100-112.

Jackson, L.F., and R.K. Webster. 1976. Race differentiation, distribution, and frequency of Rhynchosporium secalis in California. Phytopathology 66: 719-725.

Lange, B.J., and W.J.R. Boyd. 1968. Preservation of fungus spores by drying on porcelain beads. Phytopathology 58: 1711-1712.

Mayfield, A.H., and B.G. Clare. 1985. Effects of high temperatures on scald lesion development and sporulation in barley infected with Rhynchosporium secalis. Aust. J. Agric. Res. 36: 197-200.

Polley, R.W. 1971. Barley leaf blotch epidemics in relation to weather conditions with observations on the overwintering of the disease on barley debris. Plant Pathol. 20: 184190.

Ryan, C.C., and B.G. Clare. 1975. Effects of light, temperature and period of leaf-surface wetness on infection of barley by Rhynchosporium secalis. Physiol. Plant Pathol. 6: 93-103.

SAS Institute Inc. 1987. SAS/STAT Guide for personal computers. Version 6. SAS Institute Inc., Cary, NC. 1028 pp.

Schein, R.D. 1960. Physiologic and pathogenic specialization of Rhynchosporium secalis. Bull. Pennsylvania Agric. Exp. Stn. 664.

Shipton, W.A., W.J.R. Boyd, and S.M. Ali. 1974. Scald of barley. Rev. Plant Pathol. 53: 839861. 
Skoropad, W.P. 1957. Temperature and humidity relationships in securing infection of barley with Rhynchosporium secalis. Phytopathology 47: 32-33.

Williams, R.J., and H. Owen. 1973. Physiologic races of Rhynchosporium secalis on barley in Britain. Trans. Br. Mycol. Soc. 60: 223234.

Xue, G. 1990. Pathogenic variation and parasitic fitness in Rhynchosporium secalis from southern Ontario and the components of partial resistance to scald in winter barley cultivars. Ph.D. thesis, University of Guelph, Guelph, Ontario. 110 pp.

Xue, G., and R. Hall. 1991. Distribution and severity of scald on winter barley in Ontario in 1988 and 1989. Can. Plant Dis. Surv. 71: 139-141.

Xue, G., R. Hall, and D. Falk. 1991. Pathogenic variation in Rhynchosporium secalis from southern Ontario. Plant Dis. 75: 934-938. 